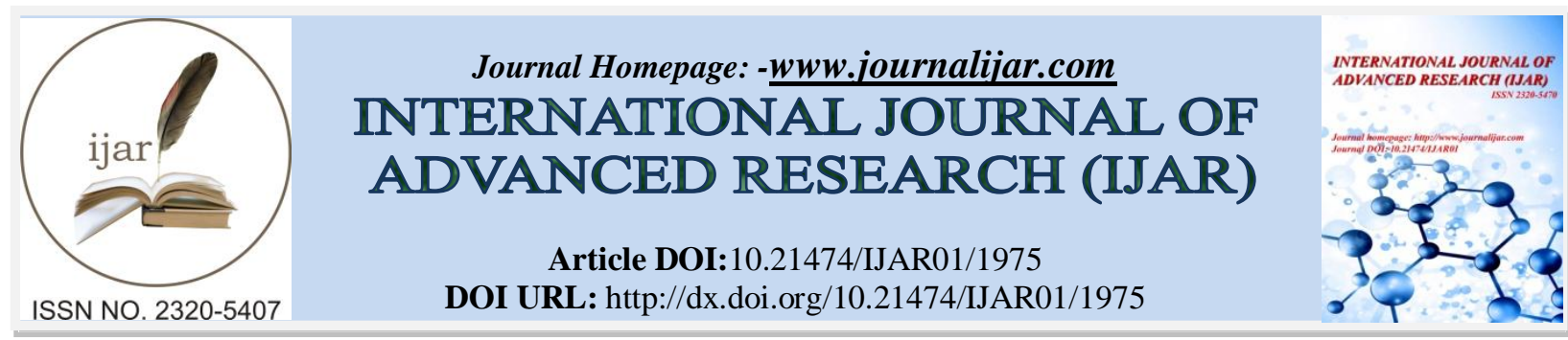

RESEARCH ARTICLE

\title{
A COMPARATIVE STUDY OF DIFFERENT DIMENSIONS OF TEACHER'S PARTICIPATION IN SCHOOL ADMINISTRATION AMONG MALE AND FEMALE TEACHERS OF SECONDARY SCHOOLS.
}

\author{
Dr. Pramod Kumar Naik ${ }^{1}$, Mr. AtindraNath Dutta ${ }^{2}$ and Ms. Ananya Jana ${ }^{3}$. \\ 1. Professor and Dean (Education), Dr. C.V. Raman University, Kota, Bilaspur, Chhattisgarh. \\ 2. Assistant Professor (Education) Dr. C.V. Raman University, Kota, Bilaspur, Chhattisgarh. \\ 3. M. Phil Scholar (Education) Dr. C.V. Raman University, Kota, Bilaspur, Chhattisgarh.
}

\section{Manuscript Info}



Manuscript History

Received: 12 August 2016

Final Accepted: 22 September 2016

Published: October 2016

Key words:-

Teacher's Participation, School

Administration, Male and Female

Teachers, Secondary Schools.

\section{Abstract}

The participation of teachers in the school administrative activities makes teachersto gain a lot of experience, remove boredom, frustration and increases commitment towards job, job efficiency and job satisfaction. This current study was conducted teachers' participation in school administration in relation to nature of school, teaching experience and their teaching subjects. The study employed "simple random sampling" as the sampling technique and was administrated on 100 teachers, including males and females, of secondary schools. "Teacher's Participation in School Administration Scale" was used as data collection tool. The scale was developed by HaseenTaj (2000). The tool was administered in 8 secondary schools of Kota Block of Bilaspur district in Chhattisgarh. The data was collected and was analysed statistically by using mean, SD and t-test. The study revealed that there is significant differences between male and female school teachers in their participation in school administration in all the five dimensions.

Copy Right, IJAR, 2016,. All rights reserved.

\section{Introduction:-}

In a school system, participation of teachers in school administration is very helpful for solving problems to achieve goals and objectives effectively and efficiently. The participation can be on curricular/instructional programmes, communication systems, staff recruitment, students/staff welfare, students/staff discipline, school plant maintenance, infrastructure, health facilities, admission policy, budgeting, purchasing, sports, co-curricular activities etc. The outcome of teachers' participation should affect teaching-learning process in a pleasant and conducive atmosphere.

The success or failure of any school or an organization is largely dependent upon the groups that make it up and effective utilization of the intellectual abilities of these group or human resources helps the development of such an organization or school. Sarwar (1991) described some of these duties as supervision of assembly, literary society; supervision of student functions; supervision of funds, fee and fines; supervision of discipline and punctuality as day master; supervision of games and sports; supervision of hostel; supervision of library, reading room; supervision of records and registers; supervision of stores; supervision of first aid and supervision of workers. According to Shahid(2000), educational administration deals with the process of validating purposes and allocating resources to achieve the maximum attainment of purposes with the minimum allocation of resources whichincludes different 
aspects of management of material equipment, management of school plant, management of human equipment and management of ideas and principles into school system, curriculum, time schedule, norms of achievement, cocurricular activities. Administration is sometimes conceptualized as the job of the school principal, which includes holding together the organization, making progress towards set objectives, and getting things done. It is also the process of organization leadership (Udoh and Akpa, 2007).

Mullins (2005) gave his opinion that many people believed that staff participation in decision making leads to higher performance and which is necessary for survival in an increasingly competitive world. Ndu and Anogbogu (2007) noted that where teachers are not involved in governance, result the teachers behaving as strangers within the school environment. Thus, most teachers do not put in their best to have full sense of commitment and dedication to the school.

\section{Significance of the study:-}

Basically most important duty of a teacher is to teach the students with effective teaching-learning process. Besides classroom instruction along the other duties which the teacher performs are as managing the pupils, looking after instructional supplies, directing out of class activities of pupils, caring for school facilities, participating in the planning of expenditure, keeping records, making reports and cultivating wholesome relations with the community are usually regarded as entirely incidental so the major responsibility of instruction. Such duties challenge the management skill of the teachers. Participation of teachers in planning is important not only to maintain good interpersonal relationships but also to strengthen administrative efficiency.

It is truly desirable that the teachers participate actively and willingly in school administrative duties and perform these properly so that the school organization can proceed in an elegant and smooth way to achieve its goals. Gender, locality, age, experience of teachers affect their participation in the duties related to school administration.

So, we see that how teachers' participation works effectively for the positive environment of the school administration. Thus the researcher has selected the problem as "A Comparative Study of Different Dimensions of Teacher's Participation in School Administration among Male and Female Teachers of Secondary Schools.”

\section{Statement of the Problem:-}

The problem for the present study is stated as follows:

“A Comparative Study of Different Dimensions of Teacher's Participation in School Administration among Male and Female Teachers of Secondary Schools.”

\section{Objectives of the study:-}

1. To study teacher's participation in school administration for the dimension of planning among male and female teachers of secondary schools.

2. To study teacher's participation in school administration for the dimension of organizing among male and female teachers of secondary schools.

3. To study teacher's participation in school administration for the dimension of communicating among male and female teacher of secondary school.

4. To study teacher's participation in school administration for the dimensionof controlling among male and female teacher of secondary school.

5. To study teacher's participation in school administration for the dimension of evaluating among male and female teachers of secondary schools.

\section{Hypotheses of the study:-}

$\mathbf{H}_{\mathbf{0 1}}$ There is no significant mean difference for the planning dimension of teacher's participation in school administration among male teachers and female teachers.

$\mathbf{H}_{\mathbf{0 2}}$ There is no significant mean difference for theorganizing dimension of teacher's participation in school administration among male teachers and female teachers.

$\mathbf{H}_{\mathbf{0 3}}$ There is no significant mean difference for thecommunicating dimension of teacher's participation in school administration among male teachers and female teachers.

$\mathbf{H}_{\mathbf{0 4}}$ There is no significant mean difference for thecontrolling dimension of teacher's participation in school administration among male teachers and female teachers.

$\mathbf{H}_{\mathbf{0 5}}$ There is no significant mean difference for theevaluating dimension of teacher's participation in school administration among male teachers and female teachers. 


\section{Method:-}

In the present study researcher has used survey method.

\section{Sample:-}

In the present study, the investigators selected the Bilaspur district of thestate Chhattisgarh as their field of investigation. Due to limitation of time the investigators had to take a limited number of institutions for data collection. A sample size of 100 of secondary level teachers from eight secondary schools were taken for this purpose. The researchers took50 male teachers and 50 female teachers from rural and urban schools. For this purpose the researchers usedstratified random sampling technique.

\section{Tool used:-}

The tool which have been used in this research study is as following:-

"Teacher's Participation in School Administration Scale (TPSAS)"

Teacher's Participation in School Administration Scale (TPSAS)has been developed by Dr. HaseenTaj.

This scale has 27 items and these are divided into 5 sections. Each section represents one dimension of teacher's participation in school administration. Among them, 5 items are related to planning, 6 are related to organizing, 07 items related to communicating, 5 items are related to controlling and 04 items are related to evaluating. There are 5 options for each item in the questionnaire as - Always, frequently, occasionally, rarely and never.

The method of answering the questions was according to 5 degree Likert which varies from 5 to 1 . The scoring for each option in each item is as following:

\begin{tabular}{|c|c|c|c|c|c|}
\hline Nature of item & Always & Frequently & Occasionally & Rarely & Never \\
\hline & 5 & 4 & 3 & 2 & 1 \\
\hline
\end{tabular}

Data were collected individually. The scoring of responses was done in accordance with the scoring key given in the manual. Statistical treatment of obtained data was done to test signification of each hypothesis.

\section{Statistical Techniques Used:-}

The scores obtained were subject to statistical treatment using proper statistical techniques. For this purpose Mean, Standard Deviation, t- test, was used. The result so obtained are interpreted and discussed in the light of problem factors to make the result meaningful.

\section{Variables:-}

Independent variable:-Male and Female teachers of rural and urban area, Dependent variable:-Teacher's Participation in School Administration.

\section{Analysis and Interpretation of Data-}

$\underline{\boldsymbol{H}}_{\mathbf{0 I}}$ : There is no significant mean difference for the planning dimension of teacher's participation in school administration among male teachers and female teachers.

Table 1:-

\begin{tabular}{|c|c|c|c|c|c|c|c|c|}
\hline Category. & $\mathrm{N}$ & Mean & SD & $\overline{\mathrm{S}_{\mathrm{ED}}}$ & $\begin{array}{l}\text { t-test } \\
\text { Value }\end{array}$ & Df & $\begin{array}{c}\text { Significance } \\
\text { Level }\end{array}$ & Interpretation \\
\hline $\begin{array}{c}\text { Male } \\
\text { teachers }\end{array}$ & 50 & 18.08 & 2.278947 & \multirow[t]{2}{*}{0.3878969} & \multirow[t]{2}{*}{11.8588} & \multirow[t]{2}{*}{98} & $0.05=>1.98$ & \multirow[t]{2}{*}{ HO1 Rejected } \\
\hline $\begin{array}{l}\text { Female } \\
\text { Teachers }\end{array}$ & 50 & 13.48 & 1.526303 & & & & $0.01=>2.62$ & \\
\hline
\end{tabular}

Interpretation of the data:-

It is inferred from the Table No. - 01 that the calculated ' $t$ ' value is 11.8588 , which is greater than the Table Value at 0.05 level i.e. 1.98 but less than at 0.01 level i.e. 2.62. Hence hypothesis no. -1 "There is no significant mean difference for the planning dimension of teacher's participation in school administration among male teachers and female teachers" is rejected. 


\section{Result:-}

It has been found that there is a significant mean difference for the planning dimension of teacher's participation in school administration among male teachers and female teachers.

$\underline{\boldsymbol{H}}_{02}$ : There is no significant mean difference for theorganizing dimension of teacher's participation in school administration among male teachers and female teachers.

Table 2:-

\begin{tabular}{|c|c|c|c|c|c|c|c|c|}
\hline Category. & $\mathrm{N}$ & Mean & $\mathrm{SD}$ & $\mathrm{S}_{\mathrm{ED}}$ & $\begin{array}{c}\text { t-test } \\
\text { Value }\end{array}$ & $\mathrm{Df}$ & $\begin{array}{c}\text { Significance } \\
\text { Level }\end{array}$ & Interpretation \\
\hline $\begin{array}{c}\text { Male } \\
\text { Teachers }\end{array}$ & 50 & 21.02 & 2.20445 & 0.545806 & 4.8369 & 98 & $0.05=>1.98$ & HO2 Rejected \\
\cline { 1 - 1 } $\begin{array}{c}\text { Female } \\
\text { teachers }\end{array}$ & 50 & 18.38 & 3.167902 & & & & $0.01=>2.62$ & \\
\hline
\end{tabular}

Interpretation of the data:-

It is inferred from the Table No. -02 that the calculated ' $t$ ' value is 4.8369 , which is greater than the Table Value at 0.05 level i.e. 1.98 and at 0.01 level i.e. 2.62. Hence hypothesis no. -2 "There is no significant mean difference for the organizing dimension of teacher's participation in school administration among male teachers and female teachers" is rejected.

\section{Result:-}

It has been found that there is a significant mean difference for the organizing dimension of teacher's participation in school administration among male teachers and female teachers.

$\underline{\boldsymbol{H}}_{03}:$ There is no significant mean difference for thecommunicating dimension of teacher's participation in school administration among male teachers and female teachers.

Table 3:-

\begin{tabular}{|c|c|c|c|c|c|c|c|c|}
\hline Category. & $\mathrm{N}$ & Mean & $\mathrm{SD}$ & $\mathrm{S}_{\mathrm{ED}}$ & $\begin{array}{c}\text { t-test } \\
\text { Value }\end{array}$ & $\mathrm{Df}$ & $\begin{array}{c}\text { Significance } \\
\text { Level }\end{array}$ & Interpretation \\
\hline $\begin{array}{c}\text { Male } \\
\text { Teachers }\end{array}$ & 50 & 26.16 & 2.907645 & 0.66309 & 6.7261 & 98 & $0.05=>1.98$ & HO3 Rejected \\
\cline { 1 - 6 } $\begin{array}{c}\text { Female } \\
\text { Teachers }\end{array}$ & 50 & 21.7 & 3.678315 & & & & $0.01=>2.62$ & \\
\cline { 1 - 3 }
\end{tabular}

Interpretation of the data:-

It is inferred from the Table No. -03 that the calculated ' $t$ ' value is 6.7261 , which is greater than the Table Value at 0.05 level i.e. 1.98 and at 0.01 level i.e. 2.62. Hence hypothesis no. -3 "There is nosignificant mean difference for thecommunicating dimension of teacher's participation in school administration among male teachers and female teachers" is rejected.

\section{Result:-}

It has been found that there is a significant mean difference for thecommunicating dimension of teacher's participation in school administration among male teachers and female teachers.

$\underline{\boldsymbol{H}}_{04}:$ : There is no significant mean difference for thecontrolling dimension of teacher's participation in school administration among male teachers and female teachers.

Table No4:-

\begin{tabular}{|c|c|c|c|c|c|c|c|c|}
\hline Category. & $\mathrm{N}$ & Mean & $\mathrm{SD}$ & $\mathrm{S}_{\mathrm{ED}}$ & $\begin{array}{c}\text { t-test } \\
\text { Value }\end{array}$ & $\mathrm{Df}$ & $\begin{array}{c}\text { Significance } \\
\text { Level }\end{array}$ & Interpretation \\
\cline { 1 - 6 } $\begin{array}{c}\text { Male } \\
\text { Teachers }\end{array}$ & 50 & 17.1 & 2.1 & 0.389102 & 7.4531 & 98 & $0.05=>1.98$ & HO4 Rejected \\
\cline { 1 - 4 } $\begin{array}{c}\text { Female } \\
\text { Teachers }\end{array}$ & 50 & 14.2 & 1.777639 & & & & $0.01=>2.62$ & \\
\cline { 1 - 3 }
\end{tabular}




\section{Interpretation of the data:-}

It is inferred from the Table No. -04 that the calculated ' $t$ ' value is 7.4531 , which is greater than the Table Value at 0.05 level i.e. 1.98 but less than at 0.01 level i.e. 2.62. Hence hypothesis no. -4 "There is no significant mean difference for thecontrolling dimension of teacher's participation in school administration among male teachers and female teachers" is accepted.

\section{Result:-}

It has been found that there is asignificant mean difference for thecontrolling dimension of teacher's participation in school administration among male teachers and female teachers.

$\underline{\boldsymbol{H}}_{0 \mathbf{5}}$ : There is no significant mean difference for theevaluating dimension of teacher's participation in school administration among male teachers and female teachers.

Table 5:-

\begin{tabular}{|c|c|c|c|c|c|c|c|c|}
\hline Category. & $\mathrm{N}$ & Mean & $\mathrm{SD}$ & $\mathrm{S}_{\mathrm{ED}}$ & $\begin{array}{c}\text { t-test } \\
\text { Value }\end{array}$ & $\mathrm{Df}$ & $\begin{array}{c}\text { Significance } \\
\text { Level }\end{array}$ & Interpretation \\
\hline $\begin{array}{c}\text { Male } \\
\text { Teachers }\end{array}$ & 50 & 13.4 & 1.574802 & 0.293612 & 7.5133 & 98 & $0.05=>1.98$ & HO5 Rejected \\
\cline { 1 - 6 } $\begin{array}{c}\text { Female } \\
\text { Teachers }\end{array}$ & 50 & 11.36 & 1.352923 & & & & $0.01=>2.62$ & \\
\hline
\end{tabular}

\section{Interpretation of the data:-}

It is inferred from the Table No. -05 that the calculated ' $t$ ' value is 1.682688 , which is accepted both at the Table Value at 0.05 level i.e. 1.98 and at 0.01 level i.e. 2.62. Hence hypothesis no. -5 "There is no significant mean difference for theevaluating dimension of teacher's participation in school administration among male teachers and female teachers" is rejected.

\section{Result:-}

It has been found that there is asignificant mean difference for theevaluating dimension of teacher's participation in school administration among male teachers and female teachers.

\section{Findings:-}

1. There is a significant mean difference for theplanning dimension of teacher's participation in school administration among male teachers and female teachers.

2. There is a significant mean difference for theorganizing dimension of teacher's participation in school administration among male teachers and female teachers.

3. There is a significant mean difference for thecommunicating dimension of teacher's participation in school administration among male teachers and female teachers.

4. There is a significant mean difference for thecontrolling dimension of teacher's participation in school administration among male teachers and female teachers.

5. There is a significant mean difference for theevaluating dimension of teacher's participation in school administration among male teachers and female teachers.

\section{Discussion:-}

The results of the study have revealed that regarding to teacher's participation in school administration, there is differences among male and female teachers. The male teachers whether from rural or urban areas are more involved in school administration in each area than their counterpart.Female teachers are in a backward position which is not a matter of pleasure.

\section{Conclusion:-}

The female teacher should come forward to participate more in school administration and the principal of the school and school management should involve them in the work of school administration so that an equilibrium can be established. In this way, the teaching-learning process and the environment of the school can reach to a desirable context. This, the government, school management should conduct researches to find out the causes of differences and lack of organizational commitment. 


\section{References:-}

Books:-

1. Garret, E. Henry, Statistics in Psychology and Education, Paragon International Publishers.

2. Naik, P.K.(2016), Research Methodology, APH Publication, New Delhi.

3. Best J. \& Kahn J., (2008), Research in Education, Tenth Edition, Prentice-Hall of India Private Limited, New Delhi.

4. Kothari, C. R., Research methodology, New age international (p) limited, publishers.

5. Shahid, S. M. (2000). Educational Administration, Majeed Book Depot, Lahore.

6. Sarwar M. R. (1991),Majeed Book Depot,Urdu Bazar, Lahore.

7. Udoh SU, Akpa GO (2007). Educational Administration in Nigeria. Theory and Practice.ISBN 978-236-049-X.

8. Mullins LJ (2005). Management and Organisational Behaviour. Seventh edition prenticeHall.

9. Anagbogu M. (2007), "Framework for Effective Management of University'sin the 21st Century in Issues in Higher Education: Research-Evidence from Sub-Saharan Africa".

\section{Published Journals:-}

- Yousuf M., Parveen Q, Arshad M., (2013), “Teachers' Participation in School Administration at Elementary Schools of Punjab", Educational Research International, Vol. 2, No. 3, ISSN 2307 - 3721

- Olorunsola E. \&Olayemi A., (2011), "Teachers participation in decision making process insecondary schools in Ekiti State, Nigeria", International Journal of Education Administration and Policy Studies Vol. 3(6), pp. 78-84, June 2011, ISSN $2141-6656$

- Duze, Chinelo O., (2011), "Students' and Teachers' Participation in Decision-Making and Impact on School Work and School Internal Discipline in Nigeria", African Research Review, Vol. 5 (2), Serial No. 19, April, 2011,200-214, ISSN 1994-9057 (Print) ISSN 2070-0083 (Online)

- Dr. Göksoy S., (2014), "Participation of Teachers in School Administration and Their Organizational Citizenship Behaviors", International Journal of Humanities and Social Science Vol. 4, No. 7; May 2014

- Mehta D., (2015), “A Study of Teacher's Participation in Decision Making: Gender Specific Roles” Assistant Professor, Faculty of Education, Banaras Hindu University, Varanasi, India, European Academic Research, Vol. II, Issue 11, February 2015, Impact Factor: 3.1 (UIF), ISSN 2286-4822.

- Gumus S., (2013), "The Effects of Teacher and School-Level Factors on Teachers' Participation in Professional Development Activities: The Role Of Principal Leadership" Mustafa Kemal University, Turkey, Journal of International Education Research, Vol. 9, No. 4, Fourth Quarter 2013.

- Choi Ho D., (2010), "Teacher Participation in Curriculum and Pedagogical Decisions: Insights into Curriculum Leadership", Educational Management Administration \& Leadership, 38: 613, 2010.

- Bayar A. \& Dr. Placier P., (2013), "Factors Affecting Teachers' Participation in Professional Development Activities in Turkey", a Dissertation Proposal Presented to the Faculty of the Graduate School at the University of Missouri in Partial Fulfilment of the Requirement for the Degree Doctor of Philosophy.

- Gayatri R., (2016), "Teacher's Participation in School Administration and Attitude towards Teaching Profession of Secondary School Teachers", Indian Streams Research Journal, Volume: VI, Issue: I, February 2016, ISSN No. 2230-7850.

- Rathee I., (2015), "Study of Participation in School Administration of Residential and Non-Residential School Teachers in Relation to their Teaching Subject and Experience" Associate Professor, Tika Ram College of Education, Sonipat (Haryana), India, International Educational E-Journal Quarterly, Volume-IV, Issue-III, 2015, ISSN 2277-2456. 